\title{
Photochemical toxicity of drugs intended for ocular use
}

\author{
Roshan Kumar Sahu ${ }^{1,2}$, Bhupendra Singh ${ }^{1}$, Shubhini A. Saraf ${ }^{1}$, Gaurav Kaithwas ${ }^{1}$, and \\ Kamal Kishor ${ }^{3}$ \\ Department of Pharmaceutical Sciences, School for Biosciences \& Biotechnology, Babasaheb Bhimrao Ambedkar \\ University, Lucknow', CSIR-Open Source Drug Discovery Unit, Council of Scientific and Industrial Research \\ Anusandhan Bhawan, New Delhi', Indian Institute of Technology, Kanpur ${ }^{3}$, India
}

Received in November 2013

CrossChecked in November 2013

Accepted in April 2014

\begin{abstract}
The present investigation was undertaken to evaluate the possible ocular phototoxicity of drugs used in ophthalmic formulations. Sulphacetamide, ketoconazole, voriconazole, diclofenac, and ketorolac were assessed in the concentrations available in the market for their ocular use. The suitable models viz Hen's Egg Test Chorioallantoic Membrane (HET-CAM) test, Isolated Chicken Eye (ICE) test, and Red Blood Cell (RBC) haemolysis test as recommended by ECVAM, ICCVAM, and OECD guidelines were performed. Results of HET-CAM and ICE tests suggest that sulphacetamide is moderately toxic in the presence of light/UV-A and very slightly irritant without irradiation. Ketoconazole and voriconazole were found slightly irritant in presence of light/UV-A and non-irritant in dark. Diclofenac and ketorolac demonstrated slight irritancy in the light and were found to be non-irritant in dark. The results suggest that some of the drugs have potential toxic effect in the presence of light. The extent of phototoxicity might get extended when used for longer time. The recommendation is that these drugs should be stored and used in the dark for a specified time and be labelled with specific instructions for patients, especially for those working longer in the sunlight.
\end{abstract}

KEY WORDS: antibacterial agents; antifungal agents; HET-CAM Test; ICE Test; NSAIDs; RBC Test

In the regulatory context the term 'eye irritation' is generally defined as the development of undesirable changes in the eye after the application of a test substance to the anterior surface of the eye, which are reversible within 21 days of treatment. The Organisation for Economic Co-operation and Development (OECD) defined the substances that cause reversible tissue changes to the eye as ocular irritants and severity of the irritancy depends on the change/damage to the eye caused by the substance (1). The changes that are not reversible over the mentioned period are classified as ocular corrosives. The toxic reaction/ocular corrosion develops due to photodegradation of pharmaceutically active compounds or sometimes excipients present in ocular formulations when exposed to UV radiations $(2,3)$.

Antibacterial agents either alone or in combination with non-steroidal anti-inflammatory drugs (NSAIDs) are the first line therapy for ophthalmic use. Among these, drugs such as sulphacetamide, ketoconazole, voriconazole, diclofenac, and ketorolac are frequently used. This investigation is an attempt to examine ocular phototoxicity of the above mentioned drugs that show photodegradation but no data has been available to support this. Five drugs primarily belonging to the category of antibacterial agents and NSAIDs, intended for ocular use, were investigated for their possible irritancy/toxicity to the eye, using 
the methods approved by international regulatory agencies viz the OECD, International Coordination Committee for the Validation of Alternative Methods (ICCVAM), and European Centre for the Validation of Alternative Methods (ECVAM).

\section{MATERIALS AND METHODS}

\section{Chemicals}

Sodium salt of sulphacetamide (N-[(4aminophenyl)sulfonyl]acetamide) (CAS number- 14480-9) was obtained from East India Pharmaceutical Works Limited, Kolkata, India as a gift sample. Ketoconazole (1-[4-(4-\{[(2R,4S)-2-(2,4Dichlorophenyl)-2-(1H-imidazol-1-ylmethyl)-1,3dioxolan-4-yl]methoxy\} phenyl)piperazin-1-yl]ethan1-one) (CAS number 65277-42-1) was procured from Biochemix Pharmaceuticals, Haryana, India. Voriconazole ((2R,3S)-2-(2,4-difluorophenyl)-3-(5fluoropyrimidin-4-yl)-1-(1H-1,2,4-triazol-1-yl)butan2-ol) (CAS number 137234-62-9) was procured from Auro Labs, Tamil Nadu, India as sterile lyophilised dried powder. Sodium salt of diclofenac (2-(2-(2,6-dichlorophenylamino)phenyl)acetic acid ) (CAS number 15307-86-5) was procured from Zee Labs Limited, Haryana, India and ketorolac tromethamine $(( \pm)$-5-benzoyl-2,3-dihydro- $1 \mathrm{H}$ pyrrolizine-1-carboxylic acid, 2-amino-2(hydroxymethyl)-1,3-propanediol) (CAS number 74103-07-4) was obtained from Sun Pharma Limited, Mumbai, India. Fluorescein sodium (3',6'-dihydroxyspiro[2-benzofuran-3,9'-xanthene]1-one) (CAS number 2321-07-5) was obtained from Garuda Chemicals, Mumbai, India. Sodium chloride (Loba Chemie, Mumbai India) (0.9\%) and sodium hydroxide (Loba Chemie, Mumbai, India) $(0.1 \%)$ (Loba Chemie, Mumbai India) were used as negative and positive controls in all the tests performed. Sodium hydroxide is recommended to be used as positive control in standard protocols (4-6). Concentrations of drugs for the experiments were decided according to the concentrations available in the market. Three concentrations of each drug were freshly prepared in normal saline before the experiment: sulphacetamide $(10,20$, and $30 \% \mathrm{w} / \mathrm{v})$, ketoconazole $(1,2$, and $3 \%$ $\mathrm{w} / \mathrm{v})$, voriconazole $(0.5,1$, and $1.5 \% \mathrm{w} / \mathrm{v})$, diclofenac $(0.05,0.1$, and $0.15 \% \mathrm{w} / \mathrm{v})$, and ketorolac $(0.2,0.4$, and $0.5 \% \mathrm{w} / \mathrm{v})$. The highest concentration of each drug was made with an intention to observe the toxic profile at higher concentrations as these concentrations might be or might not be available in many countries' markets.

\section{Toxicity testing}

Hen's Egg Test, Isolated Chicken Eye Test, and Red Blood Cell Lysis test were applied to profile the possible toxicity of selected chemicals. The methods have been approved by various national and international regulatory agencies like ICCVAM, ECVAM and the Japanese Centre for the Validation of Alternative Methods (JaCVAM). These agencies are primarily working with the objective to develop and validate methods that are an alternative to the existing animal experiments and are not related to ethical issues. The selected methods are based on animals that are available in slaughterhouses (eggs from egg farms and chicken from local slaughterhouses) and consumed as food. Hence no ethical issues are concerned with our investigation.

\section{Hen's Egg Test (HET-CAM Test)}

Chicken eggs were procured from local poultry and egg hatching farm at Lucknow, India. Fresh (not older than seven days), fertile, and clean eggs weighing between 50 and $60 \mathrm{~g}$ were used. Eggs were candled prior to use and nonviable or defective eggs were discarded. Excessively misshapen eggs or eggs with cracked or thin shells were not used. Eggs were placed in the incubator at $37 \pm 0.5{ }^{\circ} \mathrm{C}$ and $60 \pm 2 \%$ relative humidity. The day on which the eggs were placed in the incubator was considered as day one. Hand rotation was carried out five times per day until the day eight. Four eggs for each concentration of each case (light and dark) were grouped [total eggs $=4$ (each concentration) x15 (concentrations) x 2 (light and dark $)=120$ eggs were successfully grouped]. On day nine, eggs were removed for the assay. The region of air cell was cut and membrane was pared off. Using $0.9 \% \mathrm{NaCl}$, membrane was moistened using a disposable glass pipette. Eggs were placed in the incubator for $30 \mathrm{~min}$. The inner membrane was carefully removed with forceps. Approximately 0.3 $\mathrm{mL}$ of tested substances was placed directly onto the clear Chorioallantoic Membrane (CAM) surface. The surface was observed for changes for 5 min (300 s) by taking photographs (Canon EOS 1100D Camera, $12.2 \mathrm{x})$ at different time points $(0,60,120,180,240$, and $300 \mathrm{~s}$ ). Endpoints (surface changes) that were 
observed were: haemorrhage (bleeding from the vessels); vascular lysis (blood vessel disintegration); and coagulation (intra- and extra-vascular protein denaturation).

The UV-A light (10 watts, Phillips, India) was used to evaluate possible phototoxicity. UV-A bulb was assembled inside the incubator where the temperature was maintained. The scoring of surface changes was carried out according to the scoring table given in the protocol (Table 1). The observations of surface changes were translated into quantitative scoring system using Irritation Score (IS) formula given below (4):

$$
\left(\left(\left(\frac{(301-\text { Hemorrhage time })}{300}\right) \times 5\right)+\left(\left(\frac{(301-\text { Lysis time })}{300}\right) \times 7\right)+\left(\left(\frac{(301-\text { Coagulation time })}{300}\right) \times 9\right)\right.
$$

Haemorrhage time $=$ observed start (in seconds) of haemorrhage reactions on CAM

Lysis time $=$ observed start (in seconds) of vessel lysis on CAM

Coagulation time $=$ observed start (in seconds) of coagulation formation on CAM

Phototoxicity index was also measured using the formula (7):

Phototoxicity index $=\{[$ Mean score (light)-Mean score (dark)]/Mean score (dark) \}x100

\section{Isolated Chicken Eye Test (ICE Test)}

Chicken eyes were collected from chickens obtained from local slaughterhouse at Lucknow, India, where they are killed for human consumption (chicken used in the study were approximately seven weeks old weighing approximately $1.5-2.5 \mathrm{~kg}$ ). Only the eyes of healthy animals considered suitable for entry into the human food chain were used. Eyes were isolated from the eye socket without any damage. A drop of sodium fluorescein $2 \% \mathrm{w} / \mathrm{v}$ was put onto the corneal surface for $10-20 \mathrm{~s}$, and then immediately rinsed with $20 \mathrm{~mL}$ isotonic saline. Cornea was examined for potential damage. The final number of eyes used was 120 (groups and number of subjects were same as in the HET-CAM Test). Each eye was placed in an absorbent pad and the nictitating membrane was cut as well as other connective tissue. Eyes were placed in a superfusion chamber at a temperature of $32{ }^{\circ} \mathrm{C}$ with water pump according to the OECD ICE test protocol-438 (6). The entire cornea was supplied with isotonic saline from a bent stainless steel tube at a rate of $0.10-0.15 \mathrm{~mL} \mathrm{~min}^{-1}$ via a peristaltic pump. Once all eyes have been examined and approved, they were placed at $32 \pm 1.5^{\circ} \mathrm{C}$ for $45-60 \mathrm{~min}$ to be equilibrated to the test system prior to dosing. The whole system was kept in an incubator to maintain the temperature. After the equilibration period, a zero reference measurement was recorded for corneal thickness and corneal opacity to serve as a baseline (i.e., time $=0$ ). The fluorescein retention score determined at dissection was used as the baseline measurement. Liquid test substance was applied at $0.03 \mathrm{~mL}$ with a micropipette so that the entire surface of the cornea was evenly covered. Test material was applied for a total of $10 \mathrm{~s}$ and then rinsed with $20 \mathrm{~mL}$ isotonic saline at room temperature. After the rinse step, the eye was returned to the superfusion apparatus. Treated corneas were evaluated prior to treatment and starting at 0,30 , $60,90,120,150,180,210,240 \mathrm{~min}( \pm 5 \mathrm{~min})$ after the post-treatment rinse. The endpoints evaluated were corneal opacity, swelling, and fluorescein retention. Corneal swelling was determined from corneal thickness measurements made with an optical pachymeter (PachPen Pachymeter, Accutome, The Netherlands). It is expressed as a percentage and is calculated from corneal thickness measurements according to the following formula (5):

$\frac{\text { Corneal thickness at time } t \text { - Corneal thickness at time } 0}{\text { Corneal thickness at time } 0} \times 100$

Table 1 Classification scheme for irritation score in HET-CAM Test

\begin{tabular}{lcc}
\hline Photochemical damage & Score & Irritancy level \\
\hline $\begin{array}{l}\text { No visible membrane discoloration } \\
\text { Just visible membrane discoloration }\end{array}$ & Up to 0.9 & Practically none \\
\hline $\begin{array}{l}\text { Visible membrane discoloration/haemorrhage, } \\
\text { structures are covered partially }\end{array}$ & $1-4.9$ & Moderate \\
\hline $\begin{array}{l}\text { Visible membrane discolouration/ haemorrhage, } \\
\text { structures are entirely covered }\end{array}$ & $8-8.9$ & Strong \\
\hline
\end{tabular}


The mean percentage of corneal swelling for all test eyes was calculated for each observation time point. Based on the highest mean score for corneal swelling, as observed at any time point, an overall category score is then given for each test substance. Corneal opacity is calculated by using the area of the cornea that is most densely opacified for scoring. Pictures of eyes were taken (Canon EOS 1100D Camera, Taiwan, China) and the opacity was observed visually. The mean corneal opacity value for all test eyes was calculated for each observation time point. The test was performed as dark and light groups (light specifications were kept identical to the HET-CAM Test). The mean fluorescein retention values for all test eyes were observed for the 30-min observation time point. Scoring of opacity and fluorescein retention was carried out using standard scoring tables (Table 2 and Table 3) (5).

\section{Red Blood Cell Haemolysis Test}

Fresh blood samples taken from hens weighing $2 \mathrm{~kg}$ were obtained from the local slaughter house
(Lucknow, India). Blood samples were kept in tubes containing $3.2 \%$ sodium citrate (SD Fine Chemicals, Mumbai, India) solution as anti-coagulating agent. Repetitive centrifugations at $2000 \mathrm{rpm}$ (approx. 3757 g) for $10 \mathrm{~min}$ (Remi CPR-30 Plus, Mumbai, India) were carried out to remove plasma, white blood cells (WBC), and to separate red blood cells (RBC). Citrate buffer (SD Fine Chemicals, Mumbai, India) was used to store the RBCs and prevent coagulation and was used as a vehicle for RBC suspension. $\mathrm{RBC}$ was stored at $-20^{\circ} \mathrm{C}$ until use. The principle of this method is that the addition of a toxic chemical in RBC solutions causes $\mathrm{RBC}$ lysis and the haemoglobin released is measured at particular wavelength using colorimeter. Various concentrations of test samples in phosphate buffer saline (PBS) were incubated with a defined quantity of RBC suspension for 10 min with constant shaking, at room temperature. The incubation period was terminated by high speed centrifugation. The resulting supernatant was then monitored photometrically at 530 or $560 \mathrm{~nm}$ (Photocolorimeter 1313, Environmental and Scientific Instruments Co.,

Table 2 Corneal opacity scores

\begin{tabular}{|c|c|}
\hline Score & Observation \\
\hline 0 & No opacity \\
\hline 0.5 & Very faint opacity \\
\hline 1 & Scattered or diffuse areas; details of the iris are clearly visible \\
\hline 2 & $\begin{array}{l}\text { Easily discernible translucent area; details of the iris are slightly } \\
\text { obscured }\end{array}$ \\
\hline 3 & $\begin{array}{l}\text { Severe corneal opacity; no specific details of the iris are visible; size of the pupil is } \\
\text { barely discernible }\end{array}$ \\
\hline 4 & Complete corneal opacity; iris invisible \\
\hline
\end{tabular}

Table 3 Fluorescein retention scores

\begin{tabular}{cc}
\hline Score & Observation \\
\hline 0 & No fluorescein retention \\
\hline 0.5 & Very minor single cell staining \\
\hline 1 & Single cell staining scattered throughout the treated area of the cornea \\
\hline 3 & Focal or confluent dense single cell staining \\
\hline
\end{tabular}


Haryana, India) against the blank. The total haemoglobin release by positive control was taken as $100 \%$ and the tests were evaluated relative to that. The corresponding concentration at the $50 \%$ response was considered as H50 value.

\section{Protein Denaturation Test}

A $1 \%$ solution of test in PBS was incubated with defined quantity of RBC suspension for 10 min with constant shaking at room temperature. The resulting supernatants were monitored at 575 and $540 \mathrm{~nm}$ respectively. The relation between the effective concentration of $50 \%$ haemolysis and protein denaturation (relative to sodium dodecyl sulphate denaturation) is known as Lysis/Denaturation Ratio (L/D) (8). The results obtained were compared for each case as per the evaluation table given in the protocol (8). The test was performed as dark and light group. The irritancy level was scored using standard scoring table (Table 4) (8).

\section{Statistical analysis}

All data were expressed as mean scores (Mean \pm SEM, $n=4)$. For the statistical comparison the results were compared with negative and positive controls using Dunnett's Test $(* * P<0.01, * P<0.05$ were considered as significant levels). Mean values of light and dark cases were compared using student's $t$-test. Data were analysed using GraphPad Prism Software (California, USA).

\section{RESULTS}

\section{HET-CAM Test}

Image recordings were carried out at different time points to observe the changes on the membrane (Figure
1). For sulphacetamide, mean irritation scores in light case were 4.9, 7.7, and 9.8 for 10,20 , and $30 \% \mathrm{w} / \mathrm{v}$ respectively, indicating the concentration dependent irritancy. For ketoconazole these values were 5.8, 5.4, and 5.8 at 1,2, and $4 \%$ respectively. For voriconazole the classification was slight, moderate, and slight irritancy while in diclofenac moderate, slight, and slight irritancy were observed. On the contrary, ketorolac demonstrated slight irritancy at all the concentrations tested (Table 5). In all treatments, the mean irritation score was found to be higher in light in comparison to dark case.

\section{ICE Test}

Results from light case suggest the irritant potential of sulphacetamide, in a concentration-dependent manner. Ketoconazole showed moderate, slight, and moderate level of irritancy at 1,2 , and $4 \% \mathrm{w} / \mathrm{v}$ concentration respectively. Voriconazole showed very slight level of toxicity at 0.5 and $1.5 \%$ concentrations. Slight level of irritancy was observed in case of diclofenac as well. Ketorolac was found to be very slightly irritant at 0.2 and $0.5 \% \mathrm{w} / \mathrm{v}$ concentrations respectively (Table 6).

\section{RBC Test}

None of the drugs were found to be haemolytic at all concentrations tested in both light and dark cases in the RBC test. Haemolysis was observed at very high concentrations of tested drugs (Table 7).

\section{Combined phototoxicity classification}

Combined data comparison (Table 8) suggest that drugs show their possible phototoxicity on HET-CAM and ICE tests only but not on RBC test at the used concentrations. This investigation suggests that drugs exhibit phototoxicity potential at the concentrations that are available in the market.

Table 4 Irritancy level classification in RBC test (8)

\begin{tabular}{ll}
\hline Eye irritation level & Lysis/Denaturation Ratio (L/D) \\
\hline Non irritant & $>100$ \\
\hline Slightly irritant & $>10$ \\
\hline Moderately irritant & $>1$ \\
\hline Irritant & $>0.1$ \\
\hline Very irritant & $<0.1$ \\
\hline
\end{tabular}


Table 5 Mean score values and irritancy classification (4) of drugs (HET-CAM Test) Data presented as mean \pm SEM, $(n=4)$

\begin{tabular}{|c|c|c|c|c|c|}
\hline \multirow{3}{*}{ Treatment } & \multicolumn{5}{|c|}{ HET-CAM Test } \\
\hline & \multicolumn{2}{|c|}{ Dark } & \multicolumn{2}{|c|}{ Light } & \multirow{2}{*}{$\begin{array}{l}\text { Phototoxicity } \\
\text { index }\end{array}$} \\
\hline & $\begin{array}{l}\text { Mean score } \\
\text { (IS) }\end{array}$ & $\begin{array}{c}\text { Irritancy } \\
\text { classification }\end{array}$ & $\begin{array}{l}\text { Mean score } \\
\text { (IS) }\end{array}$ & $\begin{array}{c}\text { Irritancy } \\
\text { classification }\end{array}$ & \\
\hline $\begin{array}{l}\text { Negative control } \\
(\mathrm{NaCl}, 0.9 \%)\end{array}$ & 0 & None & 0 & Slight & None \\
\hline $\begin{array}{l}\text { Positive control } \\
(\mathrm{NaOH}, 0.1 \%)\end{array}$ & $11.8 \pm 0.8$ & Strong & 19.0 & Strong & 0.60 \\
\hline Sulphacetamide (10\%) & $1.6 \pm 0.52$ & Slight & $4.9 \pm 0.44 * *(\mathrm{~s})$ & Slight & 2.10 \\
\hline Sulphacetamide $(20 \%)$ & $2.4 \pm 0.19 * *$ & Slight & $7.7 \pm 0.62 * *(\mathrm{~s})$ & Moderate & 2.24 \\
\hline Sulphacetamide $(30 \%)$ & $3.5 \pm 0.39 * *$ & Slight & $9.8 \pm 0.29 * *(\mathrm{~s})$ & Strong & 1.77 \\
\hline Ketoconazole (1\%) & $1.1 \pm 0.35$ & Slight & $5.8 \pm 0.24 * *(\mathrm{~s})$ & Moderate & 4.06 \\
\hline Ketoconazole (2\%) & $0.6 \pm 0.35$ & None & $5.4 \pm 0.39 * *(\mathrm{~s})$ & Moderate & 7.44 \\
\hline Ketoconazole (4\%) & $1.8 \pm 0.42 *$ & Slight & $5.8 \pm 1.5 * *(\mathrm{~s})$ & Moderate & 2.25 \\
\hline Voriconazole $(0.5 \%)$ & $1.2 \pm 0.40$ & Slight & $4.4 \pm 0.86^{*}(\mathrm{~s})$ & Slight & 2.69 \\
\hline Voriconazole (1 \%) & $1.1 \pm 0.67$ & Slight & $6.4 \pm 0.64 * *(\mathrm{~s})$ & Moderate & 4.70 \\
\hline Voriconazole $(1.5 \%)$ & $2.2 \pm 0.24 * *$ & Slight & $4.0 \pm 0.85^{*}$ & Slight & 0.84 \\
\hline Diclofenac $(0.05 \%)$ & $<0.1$ & None & $5.4 \pm 0.67 * *$ & Moderate & 76.78 \\
\hline Diclofenac $(0.1 \%)$ & $<0.1$ & None & $4.6 \pm 0.99 * *$ & Slight & 65.35 \\
\hline Diclofenac $(0.15 \%)$ & $<0.1$ & None & $1.9 \pm 1.2$ & Slight & 25.71 \\
\hline Ketorolac $(0.2 \%)$ & $<0.1$ & None & $1.7 \pm 0.97$ & Slight & 23.21 \\
\hline Ketorolac $(0.4 \%)$ & $0.4 \pm 0.2$ & None & $8 \pm 1.6(\mathrm{~s})$ & Slight & 5.59 \\
\hline Ketorolac $(0.5 \%)$ & $0.8 \pm 0.5$ & None & $2.8 \pm 1.6$ & Slight & 2.27 \\
\hline
\end{tabular}

Statistical significance compared to negative control using Dunnett's test. $* \mathrm{P}<0.05, * * \mathrm{P}<0.01$.

$I S$ = Irritation Score; $(s)=$ significant difference between dark and light mean values (Student's t test)

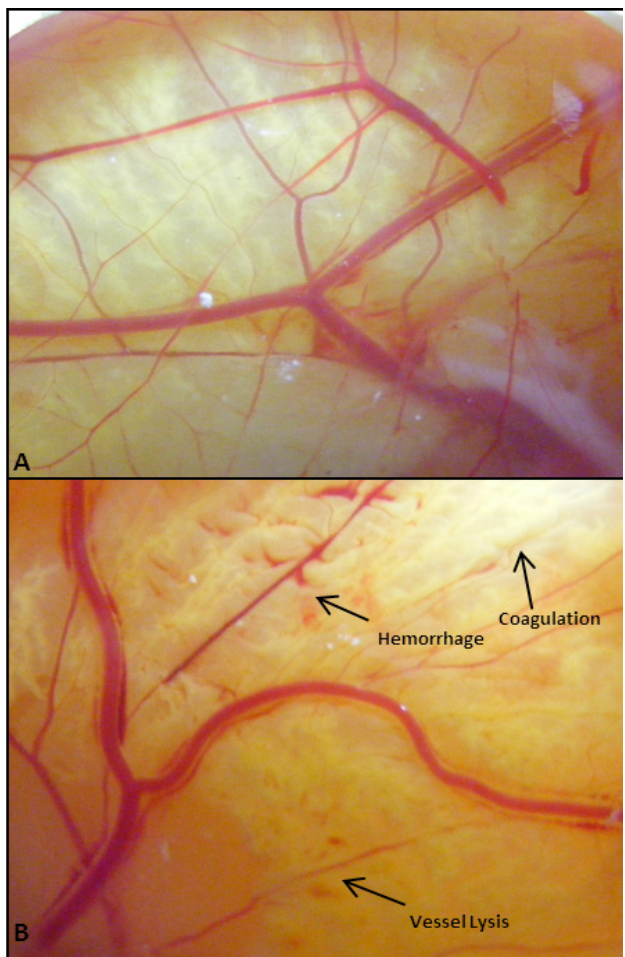

Figure 1 Images of HET-CAM Test (Light case): (A) Normal (B) Toxic

\section{DISCUSSION}

Phototoxicity is an important concern that must be considered prior to drug prescription/administration. It might cause severe cellular damage and disrupt the normal function of tissue/organ. Cells that are stressed (loaded with multiple functions at a time) and continuously change their function are more sensitive to phototoxicity (9).

Most of the antibacterial agents and NSAIDs including sulphacetamide, ketoconazole, voriconazole, diclofenac, and ketorolac are reported to get sensitised and degraded in the presence of light which might cause irritation leading to toxicity upon continuous usage (10-16). As we found, very few studies available suggested the possible phototoxicity of the investigated drugs and there were no suitable studies to validate this problem. Most of the studies were carried out by chemical analysis groups. Literature review suggested that the extent of phototoxic side-effects of these drugs depends upon their chemical structure, absorption spectra, binding of the drug to tissue, and the ability 


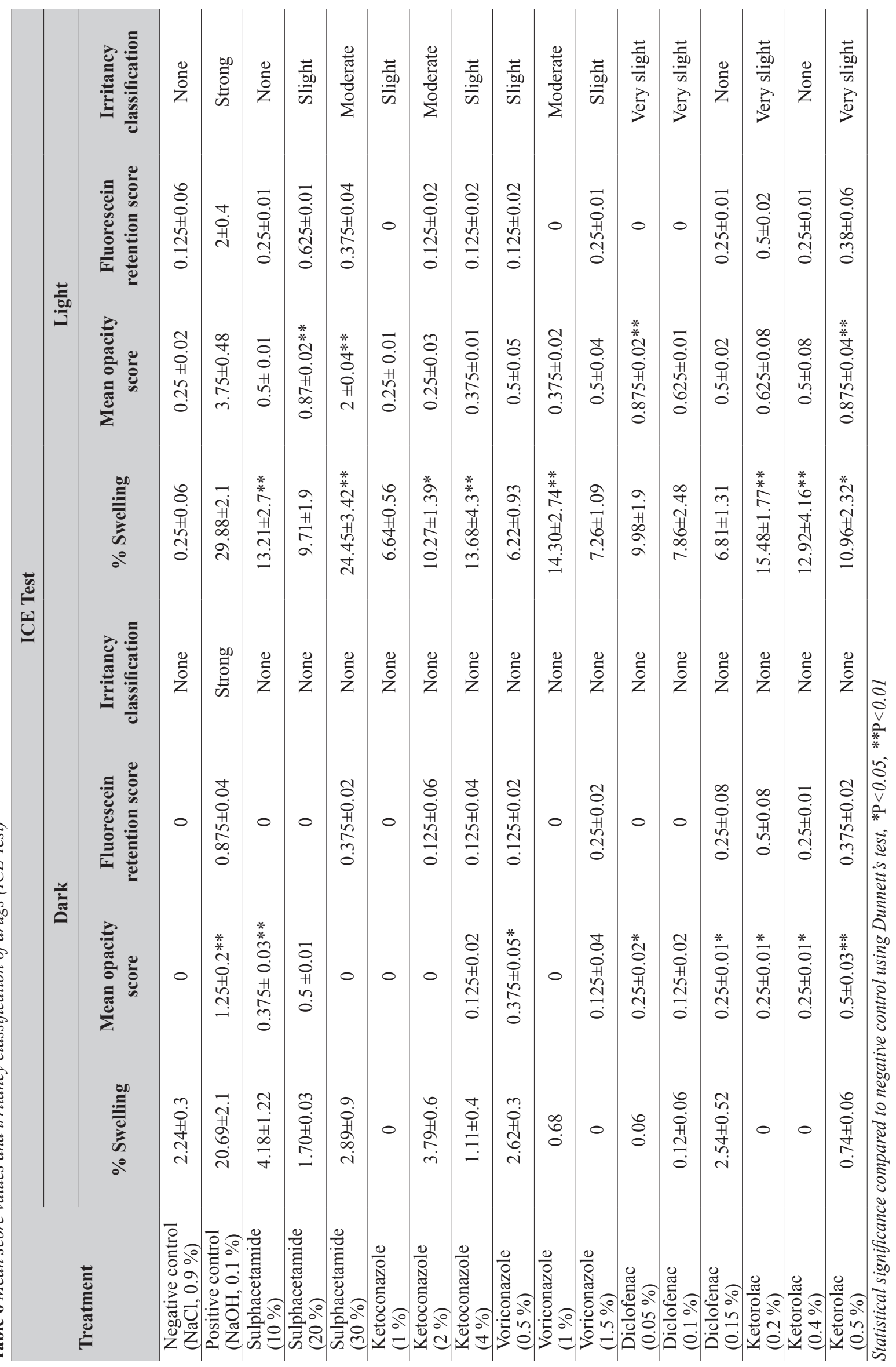


Table 7 H50/DI ratio and irritancy classification of different treatment

\begin{tabular}{|c|c|c|c|c|c|c|c|c|}
\hline \multirow[b]{2}{*}{ Treatment } & \multicolumn{4}{|c|}{ Dark } & \multicolumn{4}{|c|}{ Light } \\
\hline & $\begin{array}{c}\text { Mean } \\
\text { H50 } \\
\text { value } \\
\left(\mathrm{mg} \mathrm{mL}^{-1}\right)\end{array}$ & $\begin{array}{c}\text { DI } \\
\text { value }\end{array}$ & $\begin{array}{c}\text { H50/ } \\
\text { DI } \\
\text { ratio }\end{array}$ & $\begin{array}{c}\text { Irritancy } \\
\text { classification }\end{array}$ & $\begin{array}{c}\text { Mean } \\
\text { H50 value } \\
\left(\mathrm{mg} \mathrm{mL}^{-1}\right)\end{array}$ & $\begin{array}{c}\text { DI } \\
\text { value }\end{array}$ & $\begin{array}{c}\text { H50/ } \\
\text { DI } \\
\text { ratio }\end{array}$ & $\begin{array}{c}\text { Irritancy } \\
\text { classification }\end{array}$ \\
\hline $\begin{array}{l}\text { Negative } \\
\text { control }\end{array}$ & None & 0 & 0 & None & None & 0 & 0 & None \\
\hline Positive control & 0.92 & 59 & 0.016 & Irritant & 0.63 & 96 & 0.0 & Very irritant \\
\hline Sulphacetamide & Very high & $\begin{array}{l}\text { Very } \\
\text { high }\end{array}$ & $\begin{array}{l}\text { Very } \\
\text { high }\end{array}$ & None & Very high & $\begin{array}{l}\text { Very } \\
\text { high }\end{array}$ & 1.98 & None \\
\hline Ketoconazole & Very high & 5.79 & $\begin{array}{l}\text { Very } \\
\text { high }\end{array}$ & None & Very high & 15.31 & $\begin{array}{l}\text { Very } \\
\text { high }\end{array}$ & None \\
\hline Voriconazole & Very high & 3.48 & $\begin{array}{l}\text { Very } \\
\text { high }\end{array}$ & None & Very high & 9.65 & $\begin{array}{l}\text { Very } \\
\text { high }\end{array}$ & None \\
\hline Diclofenac & Very high & 2.56 & $\begin{array}{l}\text { Very } \\
\text { high }\end{array}$ & None & Very high & 5.33 & $\begin{array}{l}\text { Very } \\
\text { high }\end{array}$ & None \\
\hline Ketorolac & Very high & 5.23 & $\begin{array}{l}\text { Very } \\
\text { high }\end{array}$ & None & Very high & 7.26 & $\begin{array}{l}\text { Very } \\
\text { high }\end{array}$ & None \\
\hline
\end{tabular}

H50 - haemoglobin release at $50 \%$ in Red Blood Cell Haemolysis Test, DI-denaturation index

to cross blood-ocular barrier (17). It is worthwhile to mention that the literature is available to suggest the photosensitivity of these agents; however no literature elaborates on the ocular toxicity of these agents. The present study was undertaken to evaluate ocular phototoxicity of these drugs.

Sulphacetamide displayed 'slight' irritation potential in HET-CAM test (dark) in a concentration independent manner. However, in light case it showed concentration dependent toxicity and reached 'strong irritant' category at higher concentrations. These results suggest that in the presence of light, sulphacetamide is more toxic than in the dark, depending on the concentration. In ICE test similar results were observed except that the extent of toxicity was lower than in HET-CAM test. In the presence of

Table 8 Combined phototoxicity classifications

\begin{tabular}{lccl}
\hline Treatment & HET-CAM & ICE & RBC \\
\hline Sulphacetamide $(10 \%)$ & Slight & None & None \\
\hline Sulphacetamide $(20 \%)$ & Moderate & Slight & None \\
\hline Sulphacetamide $(30 \%)$ & Strong & Moderate & None \\
\hline Ketoconazole $(1 \%)$ & Moderate & Slight & None \\
\hline Ketoconazole $(2 \%)$ & Moderate & Moderate & None \\
\hline Ketoconazole $(4 \%)$ & Moderate & Slight & None \\
\hline Voriconazole $(0.5 \%)$ & Slight & Slight & None \\
\hline Voriconazole $(1 \%)$ & Moderate & Moderate & None \\
\hline Voriconazole $(1.5 \%)$ & Slight & Slight & None \\
\hline Diclofenac $(0.05 \%)$ & Very slight & Very slight & None \\
\hline Diclofenac $(0.1 \%)$ & Very slight & Very slight & None \\
\hline Diclofenac $(0.15 \%)$ & Very slight & Very slight & None \\
\hline Ketorolac $(0.2 \%)$ & None & None & None \\
\hline Ketorolac $(0.4 \%)$ & Very slight & Very slight & None \\
\hline Ketorolac $(0.5 \%)$ & Very slight & Very slight & None \\
\hline
\end{tabular}


light, sulphacetamide exists in triplet state and releases electrons. It produces $\mathrm{SO}, \mathrm{C}_{6} \mathrm{H}_{4} \mathrm{SO}_{2}$, and $\mathrm{NHR}$ radicals (10). Photodegradation is reported to occur through the supply of hydrated electrons to the tissue. These electrons interfere with bimolecular biosynthesis and cause cellular damage and modifications like depolymerisation of hyaluronic acid (11). These intermediate radicals have the ability to cause phototoxic and photoallergic effects, as observed in our study $(12,18)$.

Ketoconazole was found to be 'moderately irritant' at all concentrations in HET-CAM test whereas in ICE it displayed 'slight' to 'moderate' effect at different concentrations. Main photo-degradation products of ketoconazole are (cis-1-acetyl-4-\{4-((2-) (2chlorophenyl)-2-(1H-imidazol-1-ylmethyl)-1,3dioxolan-4-yl)methoxy)phenyl $\}$ piperazine and (cis1-acetyl-4-\{4-((2-(4-chlorophenyl)-2-(1H-imidazol1-ylmethyl)-1,3-dioxolan-4-yl)methoxy)phenyl piperazine (13). Possible mechanisms to explain ketoconazole phototoxicity include generation of singlet oxygen, superoxide anion radical, and other free radicals which cause cellular damage (14). Ketoconazole is said to lose its pharmacological activity after photodegradation (19).

Voriconazole also exhibited results similar to ketoconazole in HET-CAM and ICE tests. Voriconazole is reported to produce 1-(2, 4-difluorophenyl)-2(1H-1, 2,4-triazol-1-yl)-1-ethanone as the main photodegradation product and its major metabolites are di-hydroxyl and $\mathrm{N}$-oxide metabolites (20). Reports are available on the skin phototoxicity of voriconazole which suggest that the most likely mechanisms of its phototoxicity are related to either voriconazole (superoxide anion radical, singlet oxygen) or its $\mathrm{N}$-oxide metabolite, and retinoidal metabolic interference $(15,21,22)$.

Diclofenac and ketorolac have shown slight irritancy at all concentrations in HET-CAM test whereas in ICE test both demonstrated slight to none irritancy level in light conditions. These responses were concentration independent in both tests. Under photocatalytic conditions diclofenac releases degradation products through various chemical mechanisms: photocyclisation (2-(8-chloro-9Hcarbazol-1-yl) acetic acid, 1-chloro-8-methyl-9Hcarbazole; decarboxylation (2,6-dichloro-N-otolylbenzenamine); and dehalogenation. The products after photocyclisation are reported to cause cell lysis. $\mathrm{N}$-centred carbazolyl radical is also formed in photodegradation (16). These radical intermediates are responsible for the phototoxic effects of diclofenac sodium by hydrogen abstraction from the biomolecules, which initiates a further toxic effect. Thus, the photosensitising and phototoxic properties of diclofenac are associated with degradation products produced by light exposure (23). Ketorolac demonstrated none to very slight irritancy in a concentration independent manner. Results suggest that no significant level of phototoxicity is achieved by ketorolac. In the presence of light, triplet excited state of ketorolac is observed, which is followed by oxidation (24). This single mechanism could be accounted for the observed very slight level of toxicity by ketorolac in our investigation.

\section{Conclusion}

Our findings suggest that the investigated drugs have phototoxicity potential at the concentrations that are available in the market. This investigation also indicates that the antibacterial agents and NSAIDs having phototoxic potential can be harmful, if used for long time. The results demonstrate that the analysed drugs intended for ocular use are phototoxic and therefore should be stored and used in dark. We used models which are ex-vivo in nature. The findings have to be validated further using more pre-clinical and clinical research.

\section{REFERENCES}

1. Organisation for Economic Cooperation and Development (OECD). Guidelines for the Testing of Chemicals No. 405: Acute Eye Irritation/Corrosion. Paris: OECD; 2002.

2. Furrer P, Mayer JM, Gurny R. Ocular tolerance of preservatives and alternatives. Eur J Pharm Biopharm 2002;53:263-80. doi: 10.1016/S0939-6411(01)00246-6

3. Benavides T, Martínez V, Mitjans M, Infante MR, Moran C, Clapés P, Clothier R, Vinardell MP. Assessment of the potential irritation and photoirritation of novel amino acidbased surfactants by in vitro methods as alternative to the animal tests. Toxicology 2004;201:87-93. doi: 10.1016/j. tox.2004.04.003

4. ICCVAM Test Method Evaluation Report: Appendix G-ICCVAM Recommended HET-CAM Test Method Protocol, 2006 [displayed 2 May 2014]. Available at http://ntp.niehs. nih.gov/iccvam/docs/ocutox_docs/oteval/appg-508.pdf

5. ICCVAM-Recommended Protocol for Using the Isolated Chicken Eye (ICE) Test Method Protocol, 2012 [displayed 2 May 2014]. Availalble at http://ntp.niehs.nih.gov/iccvam/ docs/protocols/iceprotocol16jul12v2-508.pdf

6. Organisation for Economic Cooperation and Development (OECD). Guidelines for the Testing of Chemicals No 438: Isolated Chicken Eye Test Method for Identifying Ocular Corrosives and Severe Irritants. Paris: OECD; 2009. 
7. Velpandian T, Bankoti R, Humayun S, Ravi AK, Kumari SS, Biswas NR. Comparative evaluation of possible ocular photochemical toxicity of fluoroquinolones meant for ocular use in experimental models. Indian J Exp Biol 2006;44:38791. PMID: 16708892

8. INVITTOX Protocol No 37, European Centre for the Validation of Alternative Methods RBC Test System, Ispra: ECVAM DB-ALM; 2010.

9. Editors. Artifacts of light. Nat Meth. 2013;10:1135. doi: 10.1038/nmeth.2760

10. Ahmad T, Ahmed I. Multicomponent spectrophotometric assay of sulphacetamide and photodegradation products. Pak J Pharm Sci 1990;3:29-39. PMID:16414659

11. Miyazaki T, Yomota C, Okada S. Depolymerization of hyaluronate by the phototoxic drugs phenothiazines and sulphacetamide. Colloid Polymer Sci 2000;278:84-9. doi: 10.1007/s003960050014

12. Jordan L. Holtzman. Role of reactive oxygen and metabolite binding in drug toxicity. Life Sci 1982;30:1-9. doi: 10.1016/0024-3205(82)90629-4

13. Mhaske RA, Sahasrabudhe S. Identification of Major Degradation Products of Ketoconazole. Sci Pharm 2011;79:817-36. doi: 10.3797/scipharm.1107-18

14. Mohamed KN. Severe photodermatitis during ketoconazole therapy. Clin Exp Derm 1988;13:54. PMID: 3208444

15. Murayama N, Imai N, Nakane T, Shimizu M, Yamazaki H. Roles of CYP3A4 and CYP2C19 in methyl hydroxylated and $\mathrm{N}$-oxidized metabolite formation from voriconazole, a new antifungal agent, in human liver microsomes. Biochem Pharmacol 2007;73:2020-6. doi: 10.1111/j.1365-2125.2009.03534.x

16. Vogna D, Marotta R, Napolitano A, Andreozzi R, d'Ischia M. Advanced oxidation of the pharmaceutical drug diclofenac with $\mathrm{UV} / \mathrm{H}_{2} \mathrm{O}_{2}$ and ozone. Water Res 2004;38:41422. doi: $10.1016 /$ j.watres.2003.09.028
17. Roberts JE. Ocular phototoxicity. J Photochem Photobiol B 2001;64:136-43. doi: 10.1016/S1011-1344(01)00196-8

18. Motten AG, Chignell CF. Spectroscopic studies of cutaneous photosensitizing agents-III. Spin trapping of photolysis products from sulphanilamide analogs. Photochem Photobiol 1983;37:17-26. PMID: 6300940

19. Staub I, Flores L, Gosmann G, Pohlmann A, Fröehlich PE, Schapoval EES, Bergold AM. Photostability studies of ketoconazole: isolation and structural elucidation of the main photodegradation products. Latin Am J Pharm 2010;29:1100-6.

20. Adams AIH, Grace G, Paulo HS, Ana MB. LC stability studies of voriconazole and structural elucidation of its major degradation product. Chromatographia 2009;69(Supplement):115-22. doi: 10.1365/s10337-009-1082-3

21. Epaulard O, Saint-Raymond C, Villier C, Charles J, Roch N, Beani JC, Leccia MT. Multiple aggressive squamous cell carcinomas associated with prolonged voriconazole therapy in four immunocompromised patients. Clin Microbiol Infect 2010;16:1362-4. doi: 10.1111/j.1469-0691.2009.03124.x

22. Scholz I, Oberwittler H, Riedel KD, Burhenne J, Weiss J, Haefeli WE, Mikus G. Pharmacokinetics, metabolism and bioavailability of the triazole antifungal agent voriconazole in relation to CYP2C19 genotype. Br J Clin Pharmacol 2009;68:906-15. doi: 10.1111/j.1365-2125.2009.03534.x

23. Encinas S, Bosca F, Miranda MA. Phototoxicity associated with diclofenac: a photophysical, photochemical, and photobiological study on the drug and its photoproducts. Chem Res Toxicol 1988;11:946-52. doi: 10.1021/tx9800708

24. Leo G, Hi-Shi C, Johanson D. Light degradation of ketorolac tromethamine. Int J Pharmaceutics 1988;41:105-13. doi:10.1016/0378-5173(88)90142-1. 


\section{Sažetak}

\section{Fotokemijska toksičnost lijekova namijenjenih okularnoj uporabi}

Cilj ovog ispitivanja bio je istražiti moguću okularnu fototoksičnost lijekova koji se koriste u oftalmološkim formulacijama. Sulfacetamid, ketokonazol, vorikonazol, diklofenak i ketorolak ispitivani su u koncentracijama koje su dostupne na tržištu u njihovom obliku koji je namijenjen za okularnu uporabu. Primijenjeni su testovi iritacije na kokošjem jajetu (Hen's Egg Test Chorioallantoic Membrane - HETCAM), izoliranom kokošjem oku (Isolated Chicken Eye - ICE) i test hemolize crvenih krvnih stanica (Red Blood Cell - RBC) prema preporukama ECVAM-a, ICCVAM-a i OECD-a. Rezultati HET-CAM i ICE testova upućuju na umjerenu toksičnost sulfacetamida u prisutnosti svjetla/UV-A te vrlo blagu iritaciju u mraku. Ketokonazol i vorikonazol pokazali su blagu iritaciju u prisutnosti svjetla/UV-A te nikakvu iritaciju u mraku. Diklofenak i ketorolak pokazali su blagu iritaciju na svjetlu i nikakvu iritaciju u mraku. Rezultati upućuju na moguću toksičnost nekih od navedenih lijekova u prisutnosti svjetla. Razmjer fototoksičnosti može biti povećan pri produljenoj uporabi lijeka. Preporučuje se čuvati navedene lijekove na zatamnjenome mjestu te ih označiti odgovarajućim uputama za korištenje, osobito za osobe koje su dulje vrijeme izložene sunčevoj svjetlosti.

KLJUČNE RIJEČI: antibakterijski lijekovi; antimikotici; HET-CAM test; ICE test; nesteroidni protuupalni lijekovi; RBC test

\section{CORRESPONDING AUTHOR:}

Roshan Kumar Sahu

CSIR-Open Source Drug Discovery Unit, Council of Scientific and Industrial Research Anusandhan Bhawan, 2, Rafi Marg, New Delhi, India Email: roshansahu@osdd.net 